\title{
PENDAMPINGAN PENYUSUNAN APLIKASI LAPORAN KEUANGAN MASJID YANG AKUNTABEL SESUAI PSAK 45
}

\author{
Suratman ${ }^{1 *}$, Yulianti $^{2}$, Nirsetyo Wahdi ${ }^{3}$ \\ 1,2,3Fakultas Ekonomi/Jurusan Akuntansi, Universitas Semarang, Indonesia \\ ratmanr138@gmail.com ${ }^{1}$, yulianti@usm.ac.id ${ }^{2}$, nswahdi.feusm@gmail.com ${ }^{3}$
}

\begin{abstract}
ABSTRAK
Abstrak: Tujuan dalam pengabdian ini untuk merancang Aplikasi Laporan Keuangan Masjid sesuai dengan Standart Akuntansi Keuangan (PSAK-45) agar laporan keungan tersebut dapat dipertanggungjawabkan ada akuntabel kepada umat yang menginfaqkan sebagain hartanya ke masjid tersebut. Hal tersebut sebagai salah satu pertanggungjawaban ke padada masyarakat pemberi infaq. Tetapi selain itu pengurus masjid juga harus membuat laporan keuangan yang nantinya akan dilaporkan kepada takmir masjid dan kepada semua pengelola tersebut, sehingga harapannya laporan keuangan tersebut dapat disusun secara transparan sehingga tidak ada kecurigaan dari pihak manapun dan lebih-lebih sebagai pertanggungjawaban kepada Allah SWT. Dalam penyusunan laporan laporan akuntansi untuk entitas nirlaba telah diatur dalam Pedoman Standar Akuntansi Keuangan (PSAK-45) yang telah disusun oleh Ikatan Akuntan Indonesia (IAI) sebagai penyusun stantar laporan akuntansi, agar laporan keungan tersebut dapat dipertanggungjawabkan kepada masyarakat dan dapat di baca oleh pihak-pihak yang berkepentingan terhadap laporan keuangan tersebut. Kegiatan ini dilaksanakan dalam bentuk penyuluhan dan pendampingan pembuatan laporan keuangan masjid dengan aplikasi laporan keuangan yang sistematis dengan menggunakan program Microsoft Excel. Dari hasil evaluasi yang telah dailakukan bahwa hasil dari kegiatan ini sudah mampu meningkatan pemahaman dan ketrampilan dalam menyusun laporan keuangan masjid yaitu berupa Laporan Posisi Keuangan, Laporan Aktivitas, Laporan Arus Kas, dan laporan Perubahan Ekuitas.
\end{abstract}

Kata Kunci: Laporan Akuntansi; Akuntabilitas; Keuangan Masjid; PSAK45

\begin{abstract}
The purpose of this dedication is to design the Mosque Financial Report Application in accordance with the Financial Accounting Standards (PSAK-45) so that the financial report can be held accountable to the people who make a part of their wealth available to the mosque. This is one of the responsibilities given to the community giving infaq. But besides that the mosque management must also make financial reports that will later be reported to the mosque takmir and to all the managers, so that the financial statements can be arranged transparently so that there is no suspicion from any party and moreover as an accountability to Allah SWT. In preparing the accounting reports for non-profit entities, it has been regulated in the Financial Accounting Standards Guidelines (PSAK-45) that have been prepared by the Indonesian Institute of Accountants (IAI) as a compiler of accounting reports, so that the financial statements can be accountable to the public and can be read by parties parties with an interest in the financial statements. This activity was carried out in the form of outreach and assistance in making mosque financial reports with the systematic application of financial reports using the Microsoft Excel program. From the evaluation results that have been carried out that the results of this activity have been able to increase understanding and skills in preparing the mosque's financial statements in the form of Financial Position Reports, Activity Reports, Cash Flow Statements, and Equity Change reports.
\end{abstract}

Keywords: Accounting Reports; Accountability; Mosque Finance; PSAK45. 


\section{A. LATAR BELAKANG}

Pada era keterbukaan dan transparasi Laporan akuntansi dibutuhkan untuk mengelola suatu entitas baik berbasis laba maupun nirlaba. Salah satu manfaat ilmu dari Akuntansi adalah membantu manajemen dalam menyiapkan laporan keuangan (Andarsari, 2017). Laporan keuangan adalah catatan informasi keuangan dalam suatu periode yang menggambarkan Kinerja sebuah entitas. Tujuan laporan keuangan adalah menyediakan informasi posisi keuangan, kinerja perusahaan dan laporan arus kas suatu entitas yang bermanfaat bagi pengguna laporan keuangan dalam pengambilan keputusan (Purnama, 2012). Namun, sebagian besar pelaku usaha ekonomi banyak yang tidak menghiraukan tujuan dari laporan keuangan, dengan alasan menyusun laporan keuangan memakan biaya, tenaga, dan waktu. Padahal dengan laporan keuangan mereka dapat menyusun strategi untuk tujuan mengelola bisnis mereka kedepannya, sehingga tujuan yang mereka harapkan dapat tercapai. Dari pengamatan dilapangan banyak entitas (nirlaba) di Indonesia yang sebagian besar pelaporan keuangannya belum sesuai dengan standar yang berlaku, contohnya adalah Masjid (Mochammad Arif Budiman \& Mairijani, 2016). Lembaga nirlaba merupakan lembaga yang dibiayai oleh masyarakat lewat donasi atau sumbangan (Nariasih, Kurrohman, \& Andriana, 2017). Pada umumnya Masjid hanya mencatat uan masuk dan uang keluar saja. Selain itu Masjid juga tidak mencatat asset lain selain kas yang ada pada masjid tersebut, sehingga sulit untuk pengetahui posisi ke uangan masjid yang sebenarnya, padahal sudah ada standar sendiri Yang mengatur penyusunan laporan keuangan nirlaba seperti Masjid yaitu PSAK 45 (Rizky \& Padmono, 2013), (Marlinah \& Ibrahim, 2018).

Beberapa penelitian menekankan bahwa suatu organisasi non-profit seharusnya mengutamakan akuntabilitas kepada pihak beneficiari (penerima manfaat) (Andrews, 2014), sehingga dalam konteks masjid dapat dikatakan bahwa jamaah dan masyarakat di sekitar masjid merupakan pihak beneficiari yang harus memperoleh pelayanan masjid. Masjid merupakan organisasi non-profit dimana pengurus masjid berfungsi sebagai agent yang berkewajiban mengatur dan melaporkan penggunaan dana yang diberikan oleh principal (Nariasih et al., 2017), (Bustomi \& Umam, 2017). Namun kritik terhadap akuntabilitas masjid mengatakan bahwa pengendalian internal dan pengawasan pengelolaan keuangan pada organisasi masjid masih lemah (Mohamed, Aziz, Masrek, \& Daud, 2014). Hal Ini juga dikaitkan dengan kinerja masjid terhadap pengelolaan kegiatan masjid yang tidak efektif dan rendahnya profesionalitas pengurus dalam hal tata kelola (Siskawati, 2015). Akuntabilitas pada organisasi nonprofit hingga saat ini masih di dominasi oleh rasionalisasi hubungan principal-agent.

Selain itu, pada umumnya pencatatan yang dilakukan oleh pengurus Masjid masih menggunakan pencatatan manual, yang memakan waktu dan tenaga, ditambah dengan adanya risiko catatan tersebut dapat hilang, berantakan, dan tidak rapi dalam penyusunannya. Masjid tidak hanya merupakan tempat ibadah bagi umat Muslim, Masjid juga Digunakan sebagai sarana dalam mendidik anak-anak dan remaja agar dapat mendalami Ilmu agama, melakukan perayaan hari besar umat Muslim, ceramah agama, dan banyak kegaitan lainnya. Dengan banyaknya 
kegiatan tersebut pastinya Masjid membutuhkan dana yang besar dalam melakukan kegaitannya. Sebagian besar sumber dana Masjid berasal dari Sumbangan donatur atau jemaah masjid. Dana tersebut bisa berupa sumbangan donatur tetap, infak/sedekah yang diberikan oleh jemaah Masjid. Dana yang terkumpul tersebut dimasukkan kedalam kas Masjid yang dikelola oleh pengurus Masjid. Oleh karena itu sangat dibutuhkan kejelasan dan transparansi dalam pengelolaan aset Masjid.

Pengurus Masjid diharapkan dapat mengelola aset Masjid dengan sebaik-baiknya dan dapat mempertanggung-jawabkan kepada jemaah Masjid dan kepada donatur, agar donatur dan jemaah puas karena apa yang mereka sumbangkan tidak sia-sia dan semakin menambah keinginan donatur dan jemaah untuk menyisihkan pendapatan mereka agar disumbangkan ke Masjid sebagai bekal di akhirat mereka kelak. Namun pada saat sekarang ini, pengelolaan keuangan Masjid dirasa masih banyak kelemahan, seperti tidak dilakukannya pencatatan ase non ka yang dimiliki Masjid sehingga ini membuat sulitnya mengetahui posisi keuangan Masjid yang sebenarnya. Selain itu dana yang masuk tercampur aduk dalam satu rekening, sehingga besar kemungkinan dana tersebut tidak tepat sasaran dalam pendistribusiaannya.

Berawal dari masalah tersebut, tim membuat suatu rancangan laporan keuangan untuk masjid dengan menggunakan program komputer, dengan mengambil studi kasus Masjid Baitur Rasyid agar pengelolaan keuangan di Masjid menjadi lebih baik, dan pelaporan keuangannya sesuai dengan standar akuntansi yang terlah berlaku. Masjid Baitur Rasyid sebagai obyek penelitian karena Masjid Baitur Rasyid merupakan salah satu masjid di sekitar Telogosari, Masjid Baitur Rasyid berlokasi di Jl. Soekarno Hatta, Tlogosari Kulon Semarang. Dengan pencatatan keuangan yang memenuhi standar akuntansi yang berlaku yang dilakukan dengan program komputer dapat meningkatkan peran dari pengurus Masjid. Sehingga perlunya adanya pendampingan dalam penyusunan laporan keuangan Masjid yang sesuai dengan standar akuntansi yang berlaku yang telah di ditetapkan oleh Ikatan Akuntan Indonesia. Adapun Standar yang digunakan adalah Pedoman Standar Akuntansi Keuangan (PSAK) 45 yaitu sebuah standard akuntansi yang digunakan oleh Organisasi Nirlaba atau entitas non-profit. Kemudian dalam operasionalnya tidak cukup hanya sesuai dengan standard PSAK45, tapi perlu diberi kemudahan dalam rangka membukukan atau mencatat setiap transkasi akuntansi/keuangan entitas tersebut,khususnya Entitas Nirlama untuk Masjid, mengingat sumberdaya pengurus masjid tidak semua berlatas belakang dari Keuangan atau Akuntansi. Sehingga perlunya dibuatkan aplikasi siap pakai yang akan digunakan untuk sarana membukukan semua transaksi yang terjadi dalam pengelolaan keuangan Masjid sebagai pertanggungjawaban pengelola.

Berdasarkan hasil analisis situasi di atas, maka permasalahan mitra yaitu kurangnya pengetahuan tentang cara penyusunan laporan keuangan, belum ada sarana berupa program akuntansi sederhana dan belum ada pendampingan untuk menyusun laporan keuangan. Dari Permasalahan tersebut solusi yang kami tawarkan yaitu penyuluhan tentang cara menyusun laporan keuangan, membuatkan program akuntansi dengan excel dan mendampingi dalam menyusun laporan keuangan. 


\section{B. METODE PELAKSANAAN}

Mitra dalam pengabdian ini yakni Pengurus Masjid Baitur Rasyid yang berlokasi di Jl. Soekarno Hatta, Tlogosari Kulon Semarang. Adapun tahapan yang dilalui dalam pengabdian ini sesuai Gambar 1 berikut.

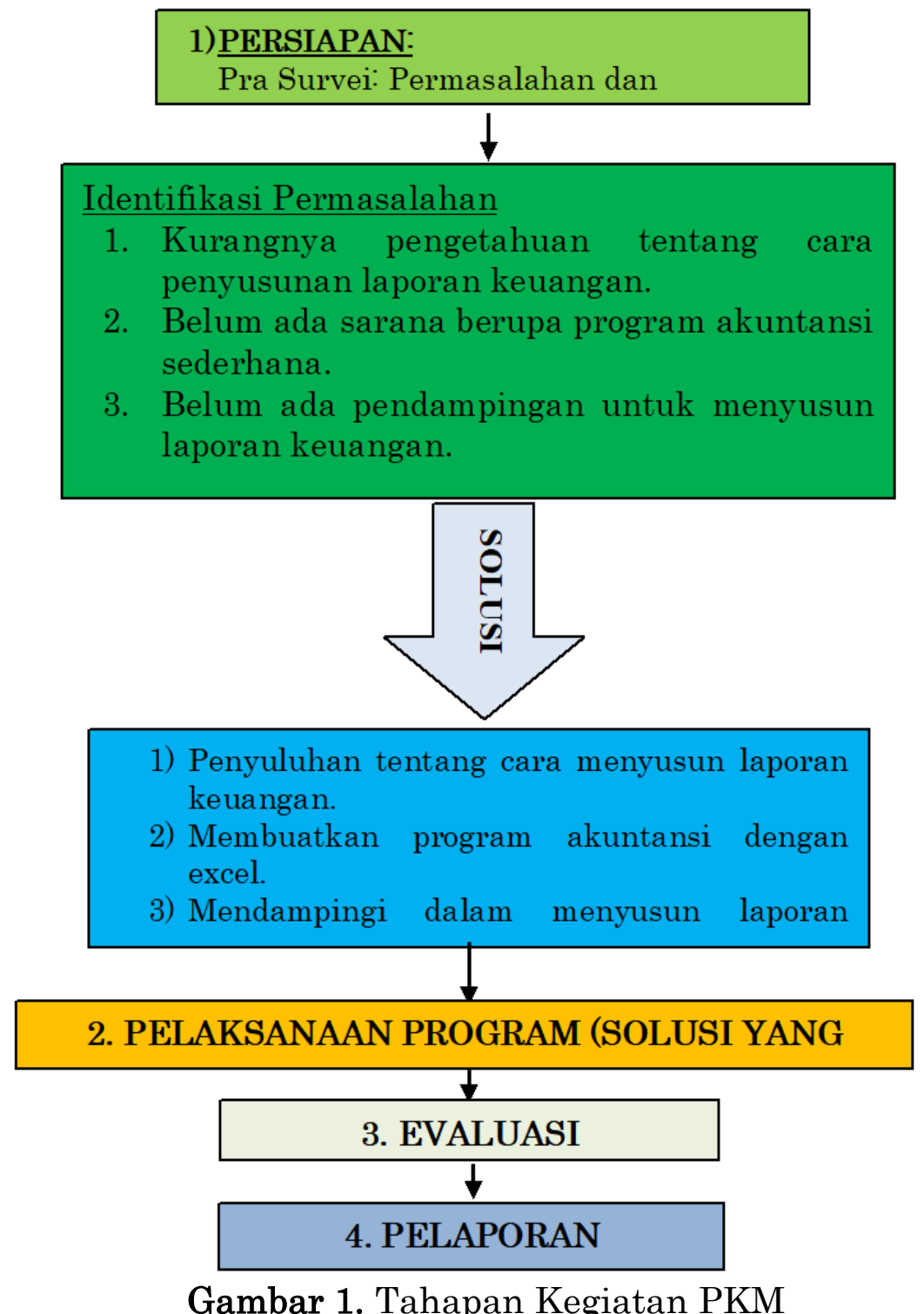

Adapun jadwal pelaksanaan pengabdian disusun sesuai Tabel 1 berikut.

Tabel 1. Kegitan Pengabdian

\begin{tabular}{|c|c|c|c|c|c|c|c|c|c|c|c|c|c|}
\hline \multirow{2}{*}{ No } & \multirow{2}{*}{ NamaKegiatan } & \multicolumn{12}{|c|}{ Bulan 2019} \\
\hline & & 1 & 2 & 3 & 4 & 5 & 6 & 7 & 8 & 9 & 10 & 11 & 12 \\
\hline 1 & Pendataan awal & & & & & & & & & & & & \\
\hline 2 & Perancangan Sistem & & & & & & & & & & & & \\
\hline 3 & $\begin{array}{l}\text { Pembuatan akun dan nama } \\
\text { perkiraan }\end{array}$ & & & & & & & & & & & & \\
\hline 4 & Penyusunan Aplikasi & & & & & & & & & & & & \\
\hline 5 & Tahap Pelaksanaan Aplikasi & & & & & & & & & & & & \\
\hline 6 & Tahap Evaluasi & & & & & & & & & & & & \\
\hline 7 & Tahap Perbaikan & & & & & & & & & & & & \\
\hline 8 & Tahap Penyelesaian Akhir & & & & & & & & & & & & \\
\hline
\end{tabular}


Pendekatan yang digunakan dalam mencapai tujuan adalah pendekatan participatory training, yaitu pendekatan yang menekankan pada partisipasi penuh dari mitra dan pendampingan dalam mencapai tujuan. Pendekatan participatory training dilakukan melalui beberapa langkah pembelajaran dalam bentuk penyuluhan dan pendampingan.

\section{HASIL DAN PEMBAHASAN}

Kegiatan pengabdian Pendapingan Penyusunan Aplikasi Laporan Keuangan Masjid sudah terlaksana dengan lancar yaitu meliputi :

\section{Pelaksanaan Kegiatan}

Pelaksanaan kegiatan pengabdian yaitu meliputi kegiatan:

a. Penyusulan menyusun laporan Keuangan Masjid.

Kegiatan ini dilaksanakan pada tanggal 03 September 2019 di aula masjid Baitur Rasyid Tlogosari kulon kecamatan Gayamsari Kota Semarang. Kegiatan ini diawali dengan menjelaskan perlunya menyusun laporan keuangan bagi masjid kepada para peserta yang merupakan pengurus masjid dan remaja masjid. Dalam rangka menciptakan transparansi keuangan masid maka pengurus masjid perlu menyusun laporan keuangan yang meliputi minimal laporan posisi keuangan, laporan aktivitas dan laporan arus kas. Untuk memperlancar dalam penyusunan laporan keuangan maka diperlukan suatu program akuntansi sederhanan dengan program excel. Dalam kegiatan ini juga di dijelaskan mengenai cara menyusun laporan keuangan masjid dengan menggunakan program akuntansi sederhana excel. Kegiatan ini diakhiri dengan penyerahan laptop yang sudah berisi program akuntansi sederhana dari tim pengabdi kepada pengurus masjid Baitur Rasyid Semarang. Suasana kegiatan penyuluhan ini tampak pada Gambar 2 berikut ini.

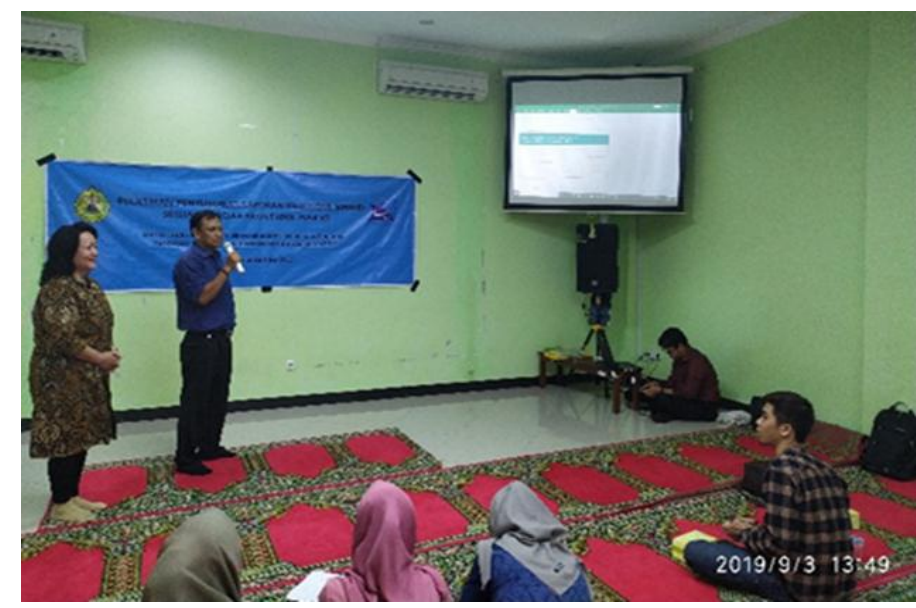

Gambar 2. Kegiatan penyuluhan

Gambar 2 menunjukkan bahwa peserta penyusulan secara serius memperhatikan materi penyuluhan yang disampaikan oleh pemateri yaitu mengenai cara menyusun laporan keuangan masjid dengan program akuntansi sederhana dengan excel. Disamping itu pemateri dan tim yang lain juga memperhatikan peserta yang mengalami kesulitan untuk menjelaskannya dan memberikan pendampingan. 
Sesi terakhir dari kegiatan penyuluhan dan pelatihan penyusunan laporan keuangan masjid ini adalah penyerahan laptop yang sudah berisi program akuntansi sederhana. Suasana tersebut tampak pada Gambar 3 berikut.

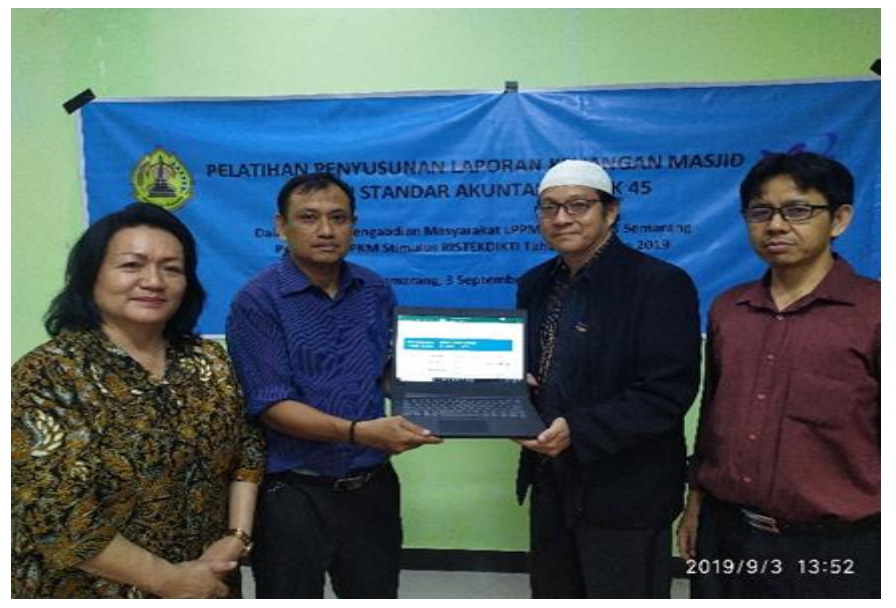

Gambar 3. Serah terima Laptop

Gambar 3 menunjukan situasi serah terima laptop yang berisi program akuntansi sederhanan untuk penyusunan laporan keuangan masjid Baitur Rasyid Semarang. Penyerahan dilakukan oleh ketuan tim pengabdian dan diterima oleh pengurus takmir Masjid. Adapun jumlah yang hadir dalam kegiatan penyuluhan ini disapikan dalam Tabel 2 berikut:

Tabel 2. Daftar Hadir Penyuluhan

\begin{tabular}{|c|l|l|l|}
\hline No & \multicolumn{1}{|c|}{ Nama } & \multicolumn{1}{c|}{ Jabatan } & \multicolumn{1}{c|}{ Instansi } \\
\hline 1 & Bambang Tutuko & Keua Takmir & Pengurus Masjid \\
\hline 2 & Tutik Ustyani & Bendahara & Pengurus Masjid \\
\hline 3 & Aditya Rizki N & Asisten Bendahara & Pengurus Masjid \\
\hline 4 & Syifa Fauziah & Remaja Masjid & Mahasiswa \\
\hline 5 & Mia Krismonnia Dewi & Remaja MAsjid & Mahasiswa \\
\hline 6 & Fadhila Ulya M & Remaja Masjid & Mahasiswa \\
\hline 7 & Eric Satna P & Remaja Masjid & Mahasiswa \\
\hline
\end{tabular}

b. Pendampingan penyusunan laporan keuangan masjid.

Kegiatan pendampingan ini dilakasanakan setelah adanya kegiatan penyuluahan tentang penyusunan laporan keuangan. Tim pengabdi mendampingi langsung bendahara masjid dalam memasukan transaksi keuangan ke dalam program akuntansi sederhana yang telah disiapkan sampai menghasilkan laporan keuangan. Gambar situasi pendampingan sesuai dengan Gambar 4 berikut: 


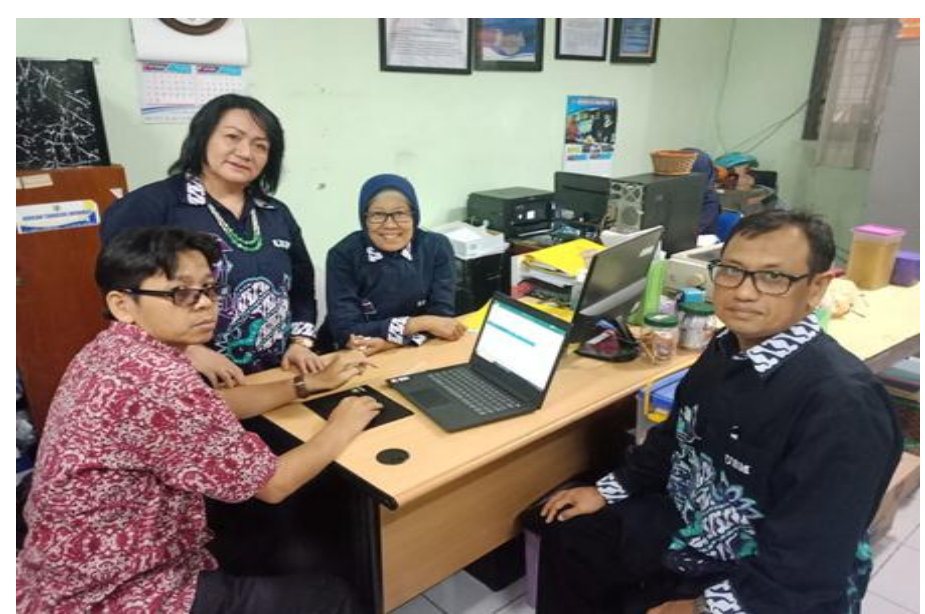

Gambar 4. Pendampingan penyusunan laporan keuangan

Gambar 4 menunjukan situasi pendapingan penyusunan laporan keuangan masjid yang diikuti oleh bendahara masjid Baitur Rasyid. Tampak pada gambar bahwa kegiatan ini diikuti secara seksama dan serius oleh bendahara masjid yang menggambar adanya keinginan untuk bias menyusun laporan keuangan masjid.

\section{Evaluasi}

Evaluasi dalam kegiatan ini dilaksudkan untuk mengetahui seberapa besar keberhasilan dari kegiatan pengabdian ini. Evaluasi dilakukan pada saat proses penyuluhan dan pendapingan berlangsung dan diakhiri dengan tanya jawab dengan peserta. Dari hasil evaluasi tersebut disampikan sebagai berikut:

a. Evaluasi selama proses penyuluhan dan pendampingan

Evaluasi proses selama penyuluhan dan pendampingan keterlibatan dan kemampuan setiap peserta dalam mengikuti kegiatan ini. Peserta diharapkan mampu memahami perlunya laporan keuangan dan mampu menyusun laporan keuangan masjid. Peserta sebagian besar mampu memahami tentang perlunya penyusunan laporan keuangan dan mampu untuk menyusun laporan keuangan dengan program akuntansi sederhana yang telah disiapkan.

b. Evaluasi pasca penyuluhan dan pendampingan

Evaluasi pasca penyuluhan dan pendampingan dilakunan dengan cara mengamati dan opservasi terhadap penyusunan laporan keuangan yang telah dilakukan oleh bendahara dan asisten bendahara. Keberhasilan dari kegiatan pengabdian ini dilihat dari kemampuan keberhasilan dalam penyusun laporan keuangan masjid. Dari hasil evaluasi bendahara masjid sudah mampu menyusun laporan keuangan yaitu berpa laporan posisi keuangan, laporan aktivitas, laporan arus kas dan laporan perubahan ekuitas. Berikut disajikan data mengenai hasil evaluasi dari kegiatan pengabdian pada Tabel 3 berikut ini : 
Tabel 3. Hasil Evaluasi Kegiatan

\begin{tabular}{|c|l|l|}
\hline No. & \multicolumn{1}{|c|}{ Program Pengabdian } & \multicolumn{1}{|c|}{ Wawancara dan Observasi } \\
\hline 1 & $\begin{array}{l}\text { Penyuluhan Penyusunan } \\
\text { Laporan Keuangan. }\end{array}$ & $\begin{array}{l}\text { Ada Peningkatan Pengetahuan } \\
\text { dalam penyusunan laporan } \\
\text { keuangan. }\end{array}$ \\
\hline 2 & $\begin{array}{l}\text { Pembuatan program akuntansi } \\
\text { dengan excel. }\end{array}$ & $\begin{array}{l}\text { Mempermudah dan } \\
\text { mempercepat dalam menyusun } \\
\text { laporan keuangan. }\end{array}$ \\
\hline 3 & $\begin{array}{l}\text { Pendampingan dalam } \\
\text { menyusun laporan keuangan. }\end{array}$ & $\begin{array}{l}\text { Mampu Peningkatan } \\
\text { ketrampilan dan ketepatan } \\
\text { dalam menyusun laporan } \\
\text { keuangan. }\end{array}$ \\
\hline
\end{tabular}

\section{SIMPULAN DAN SARAN}

Berdasarkan hasil kegiatan pengabdian kepada masyarakat yang telah diuraikan sebelumnya dapat ditarik beberapa kesimpulan yakni (1) Dengan adanya penyuluhan tentang penyuluhan cara menyusun laporan keuangan yang akuntabel dan sesuai dengan standar akuntansi keuangan mampu meningkatkan pengetahuan bendahara masjid dalam menyusun laporan keuangan; (2) Dengan adanya program akuntansi dengan excel bisa mempercepat dan mempermudah untuk menyusun laporan keuangan; (3) Dengan adanya pendampingan dalam menyusun laporan keuangan mampu meningkatkan ketrampilan dan ketepatan dalam menyusun laporan keuangan.

Saran yang dapat disampaikan yaitu menngingat menyusun laporan keuangan ini merupakan suatu pekerjaan yang secara terus menerus dan berkesinabungan maka sebaiknya dalam mengerjakan dilakukan secara rutin setiap ada transaksi sesegera mungkin dimasukan dalam program akuntansi yang sudah tersedia. Hal ini untuk menghidari penunpukan pekerjaan dan juga agar laporan keuangan dapat disajikan tepat waktu.

\section{UCAPAN TERIMA KASIH}

Tim Pengabdian Masyarakat mengucapkan terima kasih kepada (1) Direktorat Riset dan Pengabdian Masyarakat (DRPM) Direktorat Jenderal Penguatan Riset dan Pengembangan yang telah mendanai kegiatan pengabdian ini sehingga terlaksana dengan sukses; (2) Lembaga Penelitian dan Pengabdian Masyarakat (LPPM) Universitas Semarang; (3) Mitra pengabdian yaitu Pengurus Masjid Baitur Rasyid Semarang; dan (4) Semua pihak yang telah membantu kelancaran kegiatan ini.

\section{DAFTAR RUJUKAN}

Andarsari, P. R. (2017). Laporan Keuangan Organisasi Nirlaba (Lembaga Masjid). Ekonika: Jurnal Ekonomi Universitas Kadiri, 1(2). https://doi.org/10.30737/ekonika.v1i2.12

Andrews, A. (2014). Downward Accountability in Unequal Alliances: Explaining NGO Responses to Zapatista Demands. World Development, 54, 99-113. https://doi.org/10.1016/j.worlddev.2013.07.009

Bustomi, I., \& Umam, K. (2017). Strategi Pemberdayaan Ekonomi Santri Dan Masyarakat Di Lingkungan Pondok Pesantren Wirausaha Lantabur Kota Cirebon. Al-Mustashfa: Jurnal Penelitian Hukum Ekonomi Syariah, 2(1), 79. 
https://doi.org/10.24235/jm.v2i1.1625

Marlinah, A., \& Ibrahim, A. (2018). Penerapan Laporan Keuangan Organisasi Nirlaba Berdasarkan Psak No. 45 (Studi Masjid Al-Markaz AL-Islami Jenderal M. Jusuf). Akmen: Jurnal Ilmiah, 45(45), 170-188.

Mochammad Arif Budiman, \& Mairijani. (2016). Peran Masjid dalam Pengembangan Ekonomi Syariah di Kota Banjarmasin. At-Taradhi: Jurnal Studi Ekonomi, 7(2), 175-182.

Mohamed, I. S., Aziz, N. H. A., Masrek, M. N., \& Daud, N. M. (2014). Mosque Fund Management: Issues on Accountability and Internal Controls. Procedia Social and Behavioral Sciences, 145, 189-194. https://doi.org/10.1016/j.sbspro.2014.06.026

Nariasih, D. Y., Kurrohman, T., \& Andriana, A. (2017). Laporan Keuangan Masjid Berdasarkan Kombinasi PSAK Nomor 45 dan PSAK Nomor 109 (Studi Kasus Pada Masjid XYZ). E-Journal Ekonomi Bisnis Dan Akuntansi, 4(1), 6. https://doi.org/10.19184/ejeba.v4i1.4553

Purnama. (2012). Pengelolaan dan Pelaporan Keuangan pada Masjid. Jurnal Akutansi, (45), 1-10.

Rizky, D. A., \& Padmono, Y. Y. (2013). Analisis Penerapan PSAK No. 45 pada Yayasan Masjid Al-Falah Surabaya. Jurnal Ilmu \& Riset Akuntansi Vol. 2 No. $7(2013,2(7), 147$.

Siskawati, E., -, F., \& Surya, F. (2015). Model Akuntabilitas Organisasi Non Profit pada Masjid. Vol.1 No.1, 1(1), 29. https://doi.org/10.18382/jraam.v1i1.11 